\title{
Corporal Punishment In Schools: Theoretical Discussion And Personal Experience
}

\author{
Omar Abdulaziz Alsaif, Ph.D., King Saud University, Saudi Arabia
}

\begin{abstract}
This paper ponders the lasting effects of corporal punishment on students. The paper first considers the benefits and faults of corporal punishment by comparing the experiences of two generations of students and teachers. Starting with the definition of corporal punishment as applied locally and globally, the paper analyzes the reasons for its use, and the rationale of those who defend its legitimacy. The paper concludes with a discussion of the impact of the decision to ban corporal punishment in Saudi Arabian schools on Saudi students and its consequences from the students' perspective.
\end{abstract}

Keywords: Student Corporal Punishment; Saudi Arabian Schools; Violence Against Children

\section{INTRODUCTION}

hen the author was a child (around 25 years ago), he lived in a small village, Alsufrrat, in Saudi
Arabia. For three years he studied at a primary school where his father was the manager. He has
many memories of that period because his father chose a teacher, Mr. Hamad, to teach his first year. Mr. Hamad was very tall and terrifying. Students imagined him to be an evil person. He boasted that everyone in his class would receive corporal punishment, but outstanding students would receive only a slight caning, while lazy students would receive severe punishment in fulfillment of his promise. He continued to cane students because he thought that this was the best process to improve students' skills. The students' parents, including the author's parents, respected the teachers; for instance, there is a well-known proverb quoted by parents to teachers, "The flesh of my son is for you and his bones are for us." This shows that parents encourage teachers to use corporal punishment in any case, but not so violently as to cause fractures or deformities. Although the author had excellent grades, which were the best in his class, he prayed to Allah to smash all schools to end the caning. Conversely, now the author's 12-year-old son enjoys going to school and dislikes the holidays, probably because corporal punishment in Saudi Arabian schools has practically become illegal. ${ }^{1}$ Where the author's grades were excellent, his son's grades are only average and he does not care about his homework, and spends most of his time playing games. In this light, this paper will discuss the issue of corporal punishment in schools by answering a fundamental question: what are the advantages and disadvantages of corporal punishment for students?

\section{DEFINITION}

Before discussing this issue, the term 'corporal punishment' is used to limit the scope of this term. Corporal punishment is "the use of physical force with the intention of causing a child to experience pain, but not injury, for the purpose of correction or control of the child's behavior" (Straus, 1994, p. 4), such as patting, hitting, punching, and spanking "or other forms of physical punishment wherein school personnel actually strike the student with a part of the body" (Bogacki, et al., 2005, p.371). Therefore, the author excludes verbal violence such as insults and threats. Furthermore, some research differentiates between corporal punishment and physical abuse, but others "see all corporal punishment as abusive" (Hicks-Pass, 2009, p.72). Boys and girls alike could be beaten in

${ }^{1}$ Corporal punishment was illegal before May 17, 1937 (Altaiiash, 2010). 
schools, but usually "girls are beaten with less force than boys" (Archambault, 2009, p.291), maybe because male teachers are more authoritarian than female teacher (Bogacki, et al., 2005, p. 370). However, in Saudi Arabia, girls usually do not experience corporal punishment at school.

\section{THE EXTENT OF CORPORAL PUNISHMENT}

Corporal punishment is widespread in developing countries. Caroline Archambault (2009) shows us that the assistant manager of a local nongovernment organization concerned with the rights of children in Kenya told her that, "We emphasize use of excess force, torture.... You cannot say in front of children that teachers should not beat you! Because [the children] will become very arrogant" (p. 288). The assistant manager, who should care about children's rights, did not want to give children their rights; therefore, this confirms that children's rights would not be supported. In other countries, recent statistics show that "more than a million cases of corporal punishment in US schools continue to be reported annually" (Dupper \& Dingus, 2008, p. 243), and corporal punishment in US schools "is legal in 23 US states, and that 26 percent of Americans believe that elementary school teachers should be allowed to spank their students" (Starr, 2002). Therefore, physical punishment is not associated with only underdeveloped countries or ignorant people, but can be found in developed countries among educated people. Moreover, some convictions may seem difficult to change.

\section{REASONS FOR RESORTING TO CORPORAL PUNISHMENT}

When the author was a child, he wondered why Mr. Hamad resorted to violence and thought he was evil, but another teacher, Mr. Mohammad, was very kind and the author thought he was good. In addition, the author wondered why his father did not protect him and his classmates from the evil teacher.

The author's perspective is that the main reason for corporal punishment in schools is when the teacher tries to help the children to avoid bad behavior or urges them to get good results from their study at school. The author can argue this philosophical view. In addition, some teachers suffer from neurosis or mental illness, such as sadistic people, or who do not have the essential attributes for being a teacher, such as patience and forbearance. Some people also have religious justifications. For example, some researchers think biblical references endorse the use of the cane (Archambault, 2009, p. 287). Therefore, if they are using the cane only because of a religious text, they need to reinterpret their religious texts or exclude their religious beliefs from teaching. Therefore, some researchers think that religious leaders may be able "to provide religious foundations for the effective guidance of children, without the use of corporal punishment”(Dupper, p. 248).

\section{ADVANTAGES AND DISADVANTAGES OF CORPORAL PUNISHMENT}

Some researchers "found that the effects of corporal punishment differ from family to family and from culture to culture" (Hicks-Pass, 2009, p. 78), but that there are general benefits and disadvantages of corporal discipline.

In his paper, "Against the corporal punishment of children, "John Clark (2004) expresses his opinion against corporal punishment and tried to refute John Wilson's claim in 'Corporal punishment revisited' that mentioned six advantages of corporal punishment.

The first advantage Wilson mentions is that corporal punishment "is cheap and easy to administer" (Clark, 2004, p. 364) because it does not need anything, except perhaps a stick. However, some poor countries cannot employ qualified teachers who can educate difficult students or employ student advisers who can solve students' problems. Nevertheless, it is unwise to kill harmful ants using cluster munitions; therefore, when the teacher motivates his/her students, he/she should not forget that the most important thing is human dignity, because harsh physical punishment is sometimes like cluster munitions, and disproportionately harms the dignity of the child.

The second advantage of corporal punishment is that it is "affective as a deterrent, because nobody likes physical pain" (Clark, p. 365), but Clark objects to the word "nobody' because there are some people who have a sexual fetish and enjoy pain. Furthermore, he thinks "non-corporal punishment may be just as effective, but less 
brutal," and he queries corporal punishment in school if it deters the children, but then he answered, "probably not." It is the author's opinion that corporal punishment may act as a deterrent for students, but it may encourage students to avoid punishment by dishonesty or hypocrisy.

The third advantage is the effectiveness of corporal punishment as a process of reform, "in that the fear of physical pain will characteristically motivate a person not to reoffend; and the fact that the motivation is extrinsic makes it no less valuable." This point has two aspects. First, Clark asks a fundamental question: "If corporal punishment deters, does it therefore reform?", deterrence does not mean reform and may disguise long-term bad effects. Second, Clark disproves his point, "ethically, extrinsic motivation has less value than its intrinsic brethren". (Clark, p. 366).

The fourth advantage is that corporal punishment "is adjustable, in that we may easily inflict different amounts of pain on different people for different offences" (ibid., p. 366). In the author's opinion, this point is just a claim without any proof or deep meaning. However, Clark sees that a similar argument can be used for noncorporal punishment (Clark, p. 366).

The fifth advantage is that "It is fair for all, since all people are similar in their dislike of pain" (Clark, p. 367). The author mentions above that Clark states not all people are the same toward their dislike of pain, and "some people cope well with pain while others do not" (Clark, p. 367). In addition, Clark probably thinks that "equality in injustice is justice,' but this justification is unacceptable and illogical because when injustice includes everyone, that does not mean it is the best way to solve any problem.

The last advantage is that "corporal punishment does no permanent or irreversible damage" (Clark, p. 367), and Clark says that "Of the school cane, there is anecdotal evidence of permanent damage being inflicted on some children. A sensitive child, never physically punished before nor since, may never forget the one experience of corporal punishment, the effects of which could impair their adult life forever" (ibid., p. 367). Therefore, Wilson cannot predict the consequences of violence and whether they will disappear in the long term or not, because "the difficulty in clearly determining the effect of corporal punishment is related to the manner of its investigation" (Smith, et al., 2006, p. 289) and research on the long-term effects of corporal punishment "are consistent, and overwhelmingly negative over a wide variety of child development outcomes" (Smith, 2006, p. 124). In addition, the subconscious mind of children may hide their bad experiences, which affects their psychological upbringing.

Equally important is that some people think that corporal punishment is the most effective means to instill moral values in children about what is right and wrong (Archambault, 2009, p. 289), and in some cases, some children could not understand what the values meant without corporal punishment.

According to Dupper and Dingus (2008), there are other important reasons for corporal punishment, such as producing people who would conform to accepted societal norms, beating out an obstinacy seen as a syndrome of original sin, and to ensure that learning occurs (Dupper, p.244).

On the other hand, perhaps the negatives of corporal punishment are clearer than positives because many research and media reports have been performed about the disadvantages of corporal punishment. Violence has harmful effects in the short and long term. Corporal punishment might kill the child if the teacher went too far in their use of corporal punishment. In Egypt, for instance, there was a teacher who beat a pupil to death (BBC News, 2008). Violence also has the disadvantage of long-term effects (Smith, 2006, p. 117). According to the American Psychological Association (American Psychological Association APA) Website, corporal punishment causes "undesirable responses" in students, such as low self-confidence or feeling that he is "an undesirable person" (APA), and these feelings may be frustrating for the child or make him live in misery. Moreover, research shows that the child learns by imitating the behavior of adults. Therefore, "the use of physical punishment by adults having authority over children is likely to train children to use physical violence to control behavior rather than rational persuasion, education, and intelligent forms of both positive and negative reinforcement"(APA.,), so his examples will lead the matured child to use corporal punishment because he did not learn how to solve problems logically from the role modeling of his teachers. Nevertheless, "Through approximately forty-five years of research, one 
consistent theme has arisen: the use of frequent harsh physical punishment is not effective and can be detrimental" (Hicks-Pass, 2009, p. 76), but what about infrequent, mild corporal punishment?

Finally, some educators believe that the prevention of corporal punishment led to the loss of prestige of teachers and the loss of their ability to manage their students. For example, the Egyptian Minister of Education declared before the Parliament of Egypt that the educational systems make teachers "silly," and their importance must be restored (Shawqi, 2010). There are many essays and cartoons that criticize the loss of prestige of teachers (Figure 1).

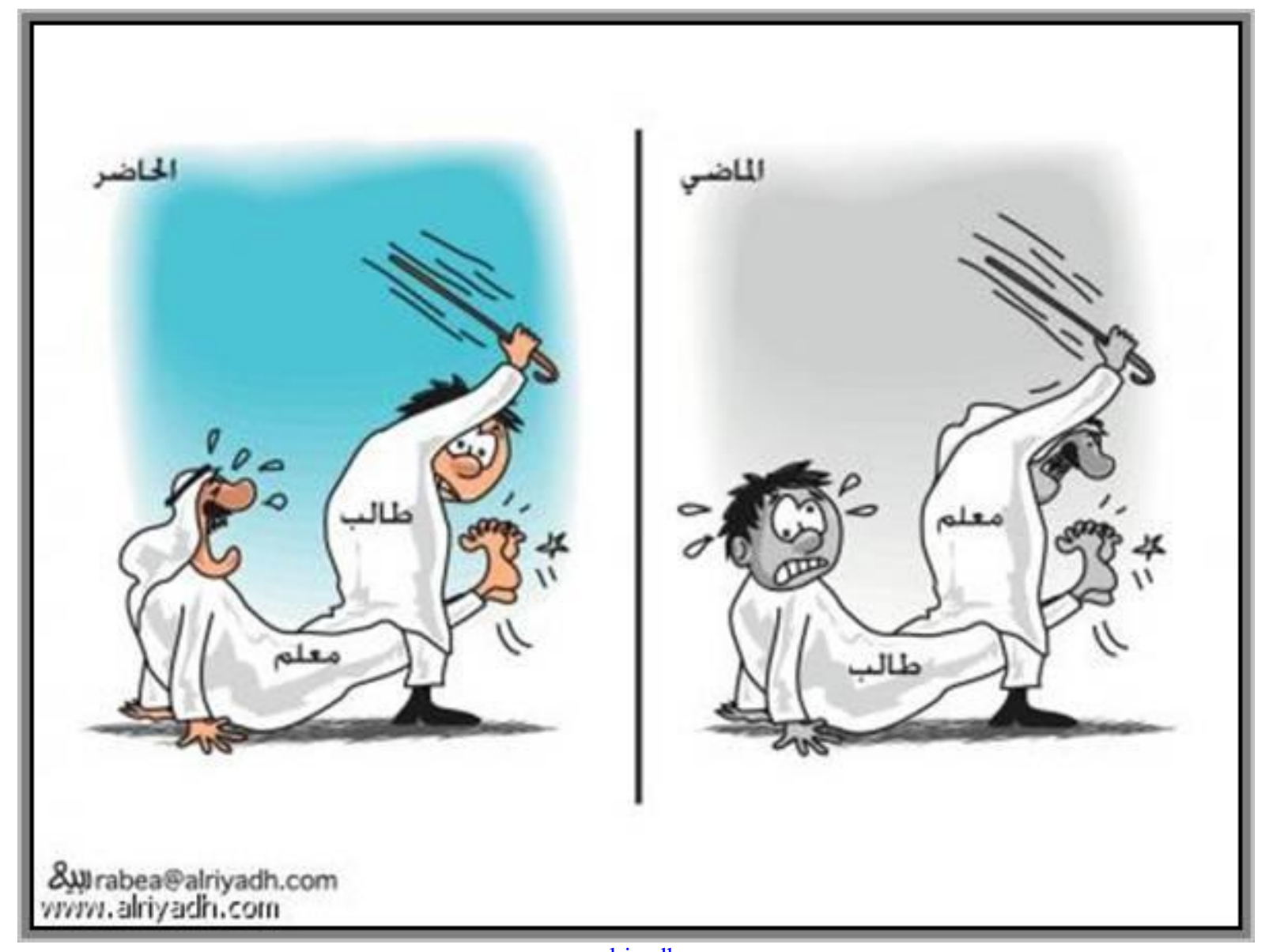

www.alriyadh.com

Figure 1

The cartoon in Figure 1 compares the power dynamic of the relationship between the student and the teacher between the present and the past. In the past (on the right), the teacher hits a child, but in the present (on the left), the student hits the teacher. There is no doubt that this cartoon exaggerates the situation.

Finally, the author' opinion is that corporal education is bad when every teacher can use it without objection. This is because the teacher may have sadistic tendencies, is aggressive, or thinks that corporal punishment is the best way to solve problems. However, corporal punishment is acceptable when some factors are taken into account such as precision in timing, intensity, and rationale. For example, when the school has used all other punishments without any improvement in the student's behavior, it can use corporal punishment, not to harm, but to say that the student's mistakes created an unsustainable situation. If the educational system authentically prevents corporal punishment, the student will think teachers will not use corporal punishment and get into trouble, but the teacher may use it if he can. In addition, the student will realize that corporal punishment is only used for extremely bad behavior because the school does not use it except in difficult cases. 


\section{CONCLUSION}

The author met a friend who had become a colleague of Mr. Hamad (mentioned earlier). They teach at the same school in Riyadh city. When the author asked him about Mr. Hamad, he mentioned that he no longer uses corporal punishment and has become very amiable with his students. He helps them to put on their shoes and plays with them. Furthermore, he is now against the use of corporal punishment by teachers. Why has he changed his method?

The educational system has probably become more stringent against any teacher who uses corporal punishment. Or perhaps Mr. Hamad has developed more awareness about the efficacy of corporal punishment. The author's view is that after his long experience he found that corporal punishment might deter students, but it cannot reform them. However, the main question to answer remains whether teachers should spend many years discovering this truth.

\section{AUTHOR INFORMATION}

Dr. Omar Alsaif is an Associate Professor of literature and criticism at King Saud University (KSU), Riyadh. He is the author of Man in Women's Poetry: Analytical Study of Feminine Poetry (2008) and The structure of the Journey in pre-Islamic poem: Myth and Symbol (2009), as well as articles on a wide range of topics related to cultural studies, feminism and literature. Dr. Omar Abdulaziz Alsaif, Associate Professor, King Saud University, College of Arts, Arabic Language Department, Riyadh, Saudi Arabia, P. O. Box 2456, Riyadh 11451, King Saud University. Email: oalsaif@ksu.edu.sa

\section{REFERENCES}

1. Altaiiash, F. (2010) 'Educational minister warns schools about using influence against students', Alwatan newspaper, $13^{\text {th }}$ Jan. Available from: http://www.alwatan.com.sa/news/newsdetail.asp?issueno=3393\&id=132080[Accessed $19^{\text {th }}$ February 2010]

2. American Psychological Association (APA) website 2010. Available from: http://www.apa.org/about/governance/council/policy/corporal-punishment.aspx $\left[\right.$ Accessed $17^{\text {th }}$ February 2010]

3. Archambault, C. (2009) 'Pain with punishment and the negotiation of childhood: An ethnographic analysis of children's rights processes in maasailand', Africa Journal, Vol. 79, pp. 282-302.

4. Bogacki, D. F. Armstrong, D. J. Weiss, K. J., (2005) 'Reducing school violence: the corporal punishment scale and its relationship to authoritarianism and pupil-control ideology', The Journal of Psychiatry \& Law, September, Vol. 33/3 (pp. 367-386), New York: Federal Legal Publications.

5. Clark, J. (2004), 'Against the corporal punishment of children', Cambridge Journal of Education, Cambridge, Vol. 34/3, pp. 363-371.

6. Dupper, D. R. \& Dingus, A. M. (2008), 'Corporal punishment in U.S. public schools: A continuing challenge for school social workers', Children \& Schools, 30, pp. 243-250.

7. Hicks-Pass, S. (2009) 'Corporal Punishment in America Today: Spare the Rod, Spoil the Child? A Systematic Review of the Literature', Best Practice in Mental Health: An International Journal, Vol. 5/2, 71-88.

8. Rabie. Riyadh Newspaper, caricatures section. Available from: http://www.alriyadh.com[Accessed $17^{\text {th }}$ February 2010]

9. Shawqi, H., (2010), 'Rights group: Education Minister approves violence against students', Almasry Alyoum Newspaper, $4^{\text {th }} \mathrm{Feb}$. Available from: http://www.almasryalyoum.com/en/news/rights-group-educationminister-statements-green-light-violence-against-students[Accessed $9^{\text {th }}$ February 2010]

10. Smith, A.B. (2006), 'The state of research on the effects of physical punishment', Social Policy Journal of New Zealand, 27 March, pp. 114-127. Available from: http://www.msd.govt.nz/documents/about-msd-andour-work/publications-resources/journals-and-magazines/social-policy-journal/spj27/27-pages114127.pdf[Accessed $19^{\text {th }}$ February 2010]

11. Smith, M., Lindsey, C. and Hansen, C., (2006) 'Corporal Punishment and the Mediating Effects of Parental Acceptance-Rejection and Gender On Empathy in a Southern Rural Population', Cross-cultural Research, 
pp. 287-305. The online version of this article can be found at :http://ccr.sagepub.com/cgi/content/abstract/40/3/287[Accessed ${ }^{2 \text { th }}$ Mach 2010]

12. Starr, L., (2002) Corporal Punishment: Teaching Violence Through Violence, Educational world website, December. Available from:http://www.educationworld.com/a_issues/starr/starr051.shtml [Accessed 19 ${ }^{\text {th }}$ February 2010]

13. Straus, M. A. (1994), Beating the devil out of them: Corporal punishment in American families, New York, Lexington Books. Its introduction and first thirty pages are available from: http://books.google.com/books?hl=ar\&lr=\&id=2pcq3UmQyCYC\&oi=fnd\&pg=PA3\&dq=schools+sado+M asochism\%22corporal+punishment\%22\&ots=dMjxTesSpL\&sig=RGK_Yi2KGHDxPtr2p8gBFKpkQtw\#v= onepage $\& \mathrm{q}=\& \mathrm{f}=$ false 